\title{
PENGARUH MODEL PEMBELAJARAN INKUIRI TERBIMBING TERHADAP PEMAHAMAN KONSEP IPA DAN SIKAP ILMIAH
}

\author{
Devi Octaviani ${ }^{1}$, I Nyoman Murda ${ }^{2}$, Dewa Nyoman Sudana ${ }^{3}$ \\ ${ }^{123}$ Universitas Pendidikan Ganesha \\ Singaraja, Indonesia \\ e-mail: devioctaviani03101997@gmail.com ${ }^{1}$, inyoman.murda@undiksha.ac.id² \\ dewanyoman.sudana@undiksha.ac.id ${ }^{3}$
}

\begin{abstract}
Abstrak
Penelitian ini bertujuan untuk 1) perbedaan yang signifikan pemahaman konsep IPA antara siswa yang dibelajarkan dengan model pembelajaran inkuiri terbimbing dan siswa yang tidak dibelajarkan dengan model pembelajaran inkuiri terbimbing, 2) perbedaan yang signifikan sikap ilmiah antara siswa yang dibelajarkan dengan model pembelajaran inkuiri terbimbing dan siswa yang tidak dibelajarkan dengan model pembelajaran inkuiri terbimbing, 3) secara simultan apakah terdapat perbedaan yang signifikan pemahaman konsep IPA dan sikap ilmiah antara siswa yang dibelajarkan dengan model pembelajaran inkuiri terbimbing dan siswa yang tidak dibelajarkan dengan model pembelajaran inkuiri terbimbing. Penelitian ini merupakan penelitian eksperimen semu (quasi experiment) dengan rancangan non-equivalent post-test only kontrol group design. Populasi dalam penelitian ini adalah seluruh kelas IV di SD di Gugus VII Kecamatan Mengwi Tahun Pelajaran 2018/2019 yang berjumlah 163 orang yang diambil dengan Teknik simple random sampling. Sampel penelitian ini yaitu siswa kelas IV SD Negeri 3 Mengwitani yang berjumlah 18 orang sebagai kelompok eksperimen dan siswa kelas IV SD Negeri 5 Mengwitani yang berjumlah 21 orang sebagai kelompok kontrol. Data penelitian dikumpulkan menggunakan metode tes dan non tes dengan instrumen tes objektif untuk mengukur pemahaman konsep IPA dan lembar kuesioner untuk mengukur sikap ilmiah siswa. Data yang diperoleh dianalisis dengan menggunakan statistik deskriptif dan statistik inferensial (Manova). Hasil penelitian menunjukkan bahwa 1)terdapat perbedaan yang signifikan pemahaman konsep IPA antara siswa yang dibelajarkan dengan model pembelajaran inkuiri terbimbing dan siswa yang tidak dibelajarkan dengan model pembelajaran inkuiri terbimbing $(0,001<0,05) 2)$ terdapat perbedaan yang signifikan sikap ilmiah antara siswa yang dibelajarkan dengan model pembelajaran inkuiri terbimbing dan siswa yang tidak dibelajarkan dengan model pembelajaran inkuiri terbimbing $(0,005<0,05) 3$ ) secara simultan terdapat perbedaan yang signifikan pemahaman konsep IPA dan sikap ilmiah antara siswa yang dibelajarkan dengan model pembelajaran inkuiri terbimbing dan siswa yang tidak dibelajarkan dengan model pembelajaran inkuiri terbimbing $(0,000<0,05)$.
\end{abstract}

Kata-kata kunci : Inkuiri Terbimbing, Sikap Ilmiah, Pemahaman Konsep IPA.

\begin{abstract}
This study aims to 1) significant differences in the understanding of science concepts between students who are taught with guided inquiry learning models and students who are not taught by guided inquiry learning models, 2) significant differences in scientific attitudes between students who are taught with guided inquiry learning models and students which is not taught by the guided inquiry learning model, 3) simultaneously whether there are significant differences in the understanding of the science concept and scientific attitudes between students who are taught with guided inquiry learning models and students who are not taught by guided inquiry learning models. This research is a quasi-experimental study (quasi experiment) with non-equivalent post-test only control group design. The population in this study were all class IV in elementary school in Cluster VII of Mengwi Subdistrict 2018/2019 Academic Year which amounted to 163 people taken by simple random sampling technique. The sample of this study is
\end{abstract}


the fourth grade students of SD 3 Mengwitani which amounted to 18 people as the experimental group and the fourth grade students of SD 5 Mengwitani which amounted to 21 people as the control group. The research data was collected using test and nontest methods with objective test instruments to measure the understanding of the science concept and questionnaire sheets to measure students' scientific attitudes. The data obtained were analyzed using descriptive statistics and inferential statistics (Manova). The results showed that 1) there were significant differences in the understanding of science concepts between students who were taught with guided inquiry learning models and students who were not taught by guided inquiry learning models $(0.001<0.05) 2)$ there were significant differences in scientific attitudes between students who learned by guided inquiry learning models and students who were not taught by guided inquiry learning model $(0,005<0,05) 3)$ simultaneously there were significant differences in the understanding of science concepts and scientific attitudes between students who were taught with guided inquiry learning models and students who did not learned by guided inquiry learning model $(0,000<0,05)$. Guided Inquiry learning model has a positive effect on the understanding of the science concept and the scientific attitude of students.

Keywords: Guided inquiry, scientific attitude, science concept

\section{Pendahuluan}

Perkembangan suatu bangsa sangat dipengaruhi oleh kualitas Sumber Daya Manusia (SDM) yang dimiliki oleh bangsa tersebut. Bangsa yang memiliki kualitas Sumber Daya Manusia (SDM) yang baik akan mampu bersaing di era globalisasi. Abad 21 ditandai oleh pesatnya perkembangan IPA dan teknologi dalam berbagai bidang kehidupan di masyarakat, terutama teknologi informasi dan komunikasi. Mata pelajaran IPA perlu diberikan kepada peserta didik khususnya di Sekolah Dasar bertujuan agar peserta didik memiliki kemampuan berfikir logis, kritis, kreatif, serta dapat beragumen secara benar yang juga dapat menunjang peningkatan kualitas Sumber Daya Manusia (SDM). Pendidikan IPA disekolah diharapkan dapat menjadi wahana bagi peserta didik untuk mempelajari diri sendiri dan alam sekitarnya, serta prospek pengembangan lebih lanjut dalam menerapkannya dalam kehidupan sehari-hari, karena hakikat IPA yaitu sebagai Produk, Proses dan juga Sikap ilmiah. Banyaknya nilai penting kehidupan yang dapat dipelajari dari IPA, memberi konsekuensi kepada para pendidik untuk dapat mengembangkan IPA sebagai salah satu media dalam membentuk pribadi siswa guna menciptakan kualitas Sumber Daya Manusia (SDM) yang baik.

Dalam pembelajaran IPA seorang pendidik dituntut untuk dapat mengajak siswa mengamati dirinya sendiri serta memanfaatkan alam sekitar sebagai sumber belajar dan berinteraksi dengan lingkungan alam yang ada disekitarnya, dengan memanfaatkan lingkungan alam sekitar siswa akan merasakan suasana belajar yang real. Oleh sebab itu pembelajaran IPA yang dilaksanakan di sekolah dasar seharusnya dapat melibatkan peserta didik baik secara fisik maupun mental.

Namun pada realitanya pembelajaran IPA di sekolah lebih banyak menekankan pada produk dibandingkan proses IPA maupun sikap IImiah yang diterapkan di beberapa sekolah dasar masih menggunakan metode pembelajaran seperti ceramah, diskusi, tanya jawab, dan penugasan yang kurang mampu meningkatkan keaktifan siswa dalam mengikuti proses pembelajaran yang dapat berdampak kepada pemahaman konsep siswa pada pelajaran IPA. Bila metode-metode tersebut selalu diterapkan tanpa mencoba model pembelajaran yang mampu meningkatkan aktivitas siswa dalam proses pembelajaran maka keterlibatan siswa dalam proses pembelajaran IPA menjadi kurang maksimal dan akan cenderung Teacher Center (berpusat pada guru).

Berdasarkan hasil wawancara bersama guru wali kelas IV SD Gugus VII Kecamatan Mengwi, Kabupaten Badung terkait dengan proses pembelajaran IPA yang telah dilaksanakan dan diperoleh hasil yaitu: 1) guru mengungkapkan dalam pembelajaran IPA masih banyak 
siswa yang cenderung tertinggal dimana guru sering memperhatikan beberapa siswa yang memerlukan waktu lebih lama untuk menyerap materi bahkan menjawab soal yang diberikan oleh guru. 2) guru juga menyatakan bahwa dalam proses pembelajaran menggunakan kurikulum 2013 cenderung penerapannya hanya guna menyelesaikan materi sehingga apabila terdapat siswa yang belum memahami betul dan terdapat hari libur karena adanya suatu hal guru sering melangkahi beberapa materi ajar, 3) guru mengungkapkan perubahan kurikulum berimbas pada kedalaman materi ajar yang dibelajarkan pada siswa khususnya pada pelajaran IPA, 4) dalam proses pembelajaran sikap ilmiah siswa juga sangat kurang dimana seharusnya diharapkan tinggi.

Setelah melakukan wawancara dilaksanakan kegiatan pengamatan proses pembelajaran IPA dari tanggal 7 sampai 14 Januari 2018 di SD Gugus VII Kecamatan Mengwi Kabupaten Badung, diperoleh hasil sebagai berikut. 1) di dalam proses pembelajaran masih terjadi interaksi satu arah dimana siswa kurang berperan aktif di dalam kegiatan pembelajaran tersebut. 2) rasa ingin tahu siswa masih kurang hal tersebut terlihat setiap kali guru bertanya atau menyajikan sebuah peristiwa siswa hanya diam saja seperti contoh observasi yang dilaksanakan di SD 3 Mengwitani terlihat sekitar 12 siswa masih kurang memiliki rasa ingih tahu yang tinggi. 3) pada saat proses pembelajaran siswa cenderung mendengarkan tanpa fokus sehingga materi yang diajarkan tidak didengarkan secara baik. 4) kurangnya pemberian variasi dalam proses pembelajaran seperti penggunaan metode atau model pembelajaran sehingga siswa cenderung mudah bosan serta kegiatan pembelajaran yang terlaksana guna hanya untuk menyelesaikan materi saja.

Untuk melengkapi hasil wawancara dan pengamatan yang telah dilaksanakan di Gugus VII Kecamatan Mengwi Kabupaten Badung, maka dilaksanakan pencatatan dokumen. Berdasarkan hasil pencatatan dokumen dapat dilihat bahwa pemahaman konsep IPA siswa kelas IV di Gugus VII Kecamatan Mengwi Kabupaten Badung yang mencapai KKM lebih rendah yaitu $44 \%$ sedangkan siswa yang belum mencapai $\mathrm{kkm}$ yaitu $56 \%$. Dengan demikian dapat disimpulkan bahwa pemahaman konsep IPA siswa kelas IV di Gugus VII Kecamatan Mengwi Kabupaten Badung masih tergolong rendah.

Riastini (2016) mengemukakan bahwa pembelajaran IPA dapat dibagi menjadi tiga yaitu IPA sebagai Produk, IPA sebagai Proses dan IPA sebagai Sikap IImiah. Untuk meningkatkan kualitas pembelajaran IPA di sekolah dasar, maka pemahaman konsep terhadap objek IPA sangat diperlukan. Untuk meningkatkan pemahaman konsep IPA pada siswa tentunya diperlukan upaya yang inovatif dalam pembelajaran yang membuat siswa tertarik untuk belajar IPA. Salah satu model pembelajaran yang sesuai dengan hal tersebut adalah model Inkuiri Terbimbing. Sond dan Trow Brdge (dalam Nurdin, 2016:217) mengemukakan Inkuiri Terbimbing atau guide inkuiri adalah suatu kegiatan dimana siswa memperoleh pedoman sesuai dengan yang dibutuhkan. Pedoman-pedoman tersebut biasanya berupa pertanyaanpertanyaan yang membimbing. Dalam penerapan model Inkuiri Terbimbing juga diharapkan dapat mempengaruhi sikap ilmiah siswa dalam pembelajaran IPA. "Sikap IImiah merupakan sikap yang perlu dikembangkan dalam pembelajaran melalui berbagai kegiatan ilmiah, seperti diskusi, penyelidikan, simulasi, atau kegiatan proyek" (Riastini, 2016:16).

Pemilihan Model Pembelajaran Inkuiri Terbimbing sebagai solusi dalam penelitian ini tentunya didasari oleh beberapa hal salah satunya adalah karena Model Pembelajaran Inkuiri Terbimbing memiliki beberapa keunggulan seperti yang dirumuskan oleh Roetiyah (dalam Nurdin, 2016) yaitu (1)dapat membentuk dan mengembangkan "self concept" pada diri siswa sehingga siswa dapat menegerti tentang konsep dasar ide-ide lebih baik, (2) membantu dalam menggunakan ingatan daan transfer pada situasi proses belajar yang baru, (3) mendorong siswa untuk berfikir dan bekerja atas inisiatifnya sendiri bersikap objektif, jujur dan terbuka, (4) mendorong siswa untuk berfikir intuituf dan merumuskan hipotesisnya sendiri, (5)memberi kepuasan yang bersifat intrinsic, (6) situasi proses belajar menjadi lebih merangsang, (7) dapat mengembangkan bakat atau kecakapan individu, (8) memberi kebebasan siswa untuk belajar sendiri, (9) siswa dapat menghindari cara-cara belajar tradisional, (10) dapat memberikan waktu pada siswa secukupnya sehingga mereka dapat mengasimilasi dan mengakomodasi informasi. 


\section{Metode}

Penelitian ini merupakan penelitian eksperimen karena dalam penelitian ini mengungkapkan hubungan sebab akibat, dengan cara melibatkan kelompok kontrol dan kelompok eksperimen. Pada penelitian yang akan dilakukan tidak memungkinkan untuk mengadakan kontrol/manipulasi terhadap semua variabel yang relevan. Oleh karena itu penelitian ini termasuk penelitian eksperimen semu (quasi experiment).Penelitian ini menggunakan rancangan non equivalent post-test only kontrol group design. Secara prosedural mengikuti pola seperti yang ditunjukkan disajikan pada Tabel 1 berikut.

Table 1. Hasil Nonequvalent Post-Test Olny Control Group Desain

\begin{tabular}{lll}
\hline Kelas & Perlakuan & Post-test \\
\hline Eksperimen & $\mathrm{X}_{1}$ & $\mathrm{O}_{1}$ \\
Kontrol & - & $\mathrm{O}_{2}$ \\
\hline
\end{tabular}

Keterangan

(sumber: dimodifikasi dari Gall dalam Agung, 2014)

X1 : Perlakuan dengan mengunkan model Inkuiri Terbimbing

- $\quad$ : Perlakuan dengan tidak mengunkan model Inkuiri Terbimbing

O1: Post-Test terhadap Kelas Eksperimen

O2 : Post-Test terhadap Kelas Kontrol

Populasi adalah keseluruhan objek dalam suatu penelitian. Menurut Sudjana, 1975: 5 (dalam Agung, 2014: 69), yang dimaksud dengan populasi adalah totalitas semua nilai yang mungkin, hasil menghitung maupun pengukuran, kuantitatif maupun kualitatif daripada karakteristik tertentu mengenai sekumpulan objek yang lengkap dan jelas. Populasi pada penelitian ini adalah semua siswa kelas IV di SD Gugus VII Kecamatan Mengwi Tahun Pelajaran 2018/2019 yang berjumlah 8 sekolah. Seluruh anggota populasi berjumlah 163 siswa. Sampel ialah "sebagian dari populasi yang diambil, yang dianggap mewakili seluruh populasi yang diambil dengan menggunakan teknik tertentu" (Agung, 2014:69). Ali (dalam Agung, 2014) menyatakan bahwa teknik yang digunakan mengambil sampel dari populasi disebut 'teknik sampling'.

Sampel yang akan digunakan dalam penelitian ini menggunakan probability sampling dengan jenis simple random sampling atau sampel acak sederhana. Pada teknik ini, semua anggota dalam populasi mempunyai kesempatan yang sama untuk dipilih menjadi sampel, sehingga pengundian dilakukan dengan sistem pengambilan secara acak. Dua kelas yang muncul dalam undian langsung dijadikan kelas sampel. Kelas sampel yang didapatkan, kemudian diundi lagi untuk menentukan kelas eksperimen dan kelas kontrol. Jumlah sampel penelitian ini adalah 39 siswa yang terbagi menjadi 2 kelompok yakni 18 siswa pada kelompok eksperimen dan 21 siswa pada kelompok kontrol. Dari delapan SD yang ada di Gugus VII Kecamatan Mengwitani Kabupaten Badung Tahun Pelajaran 2018/2019, dilakukan dua kali pengundian. Pengundian tahap pertama untuk memilih dua kelas yang dijadikan sampel penelitian. Kemudian, kedua kelas yang terpilih menjadi sampel diundi kembali untuk menentukan kelas eksperimen dan kelas kontrol. Berdasarkan undian yang dilakukan SDN 3 Mengwitani muncul paling pertama dan dijadikan kelompok eksperimen sedangkan SDN 5 Mengwitani muncul kedua dan dijadikan kelas kontrol.

Instrumen pengumpulan data yang digunakan dalam penelitian ini adalah berupa tes objektif pemahaman konsep IPA dan lembar kuisioner sikap ilmiah. Soal objektif yang digunakan terdiri dari 30 butir soal. Sedangkan lembar kuisioner sikap ilmiah terdiri dari 7 dimensi sikap ilmiah. Untuk menentukan butir soal instrumen tersebut layak untuk diberikan terhadap kelompok sampel terlebih dahulu dilakukan validasi instrumen. Validasi tes pemahaman konsep IPA meliputi: validitas isi menggunakan rumus Gregory validitas butir tes menggunakan rumus korelasi point biserial, reliabilitastes tes menggunakan KR-20, daya beda 
tes, dan tingkat kesukaran tes. Sedangkan uji coba untuk lembar kuisioner sikap ilmiah meliputi: validitas isi menggunakan rumus Gregory.

Penelitian ini dianalisis secara deskriptif dan inferensial. Analisis yang digunakan untuk menganalisis satu variabel bebas (model pembelajaran Inkuiri Terbimbing) terhadap dua variabel terikat yakni data pemahaman konsep IPA dan sikap IImiah siswa adalah dengan menggunakan analisis Multivariate Analisis of Varience (Manova) yang dilakuan dengan bantuan SPSS 21 for Windows.

\section{Hasil dan Pembahasan}

Pada penelitian ini yang dibandingkan adalah: (1) pemahaman konsep IPA siswa yang mengikuti model pembelajaran Inkuiri Terbimbing, (2) sikap ilmiah yang mengikuti model pembelajaran Inkuiri Terbimbing, (3) pemahaman konsep IPA siswa yang tidak mengikuti model pembelajaran inkuiri terbimbing, (4) sikap ilmiah yang tidak mengikuti model pembelajaran inkuiri terbimbing.

Tabel 2. Rangkuman Statistik Deskriptif Variabel Penelitian

\begin{tabular}{lcccc}
\hline \multirow{2}{*}{ Statistik } & \multicolumn{2}{c}{ Kelas Eksperimen } & \multicolumn{2}{c}{ Kelas Kontrol } \\
\cline { 2 - 5 } & $\begin{array}{l}\text { Pemahaman } \\
\text { IPA }\end{array}$ & $\begin{array}{c}\text { KonsepSikap } \\
\text { Ilmiah }\end{array}$ & $\begin{array}{c}\text { Pemahaman } \\
\text { IPA }\end{array}$ & $\begin{array}{c}\text { KonsepSikap } \\
\text { Ilmiah }\end{array}$ \\
\hline $\mathrm{N}$ & 18 & 18 & 21 & 21 \\
\hline Mean & 25,06 & 127,67 & 21,00 & 114,19 \\
\hline Median & 26,00 & 127,00 & 21,00 & 113,69 \\
\hline Modus & 30,00 & 127,00 & 21,00 & 114,31 \\
\hline Standar Deviasi & 31,18 & 15,78 & 24,72 & 12,56 \\
\hline Minimum & 18 & 105 & 17 & 98 \\
\hline Maksimum & 30 & 150 & 26 & 138 \\
\hline
\end{tabular}

Berdasarkan hasil analisis deskriptif yang telah dilakukan mengenai pemahaman konsep IPA dan sikap ilmiah, menunjukkan bahwa pada pemahaman konsep IPA sebaran data kelas eksperimen mean sebesar 25,06 modus sebesar 30,00 median sebesar 26,00 skor maksimum 30 , skor minimum 15 . Sementara sebaran data pada kelas kontrol mean sebesar 21,00 modus sebesar 21,00 median sebesar 21,00 skor maksimum 26 skor minimum 17. Dari sebaran data skor pemahaman konsep IPA pada kelas eksperimen dan kelas kontrol menunjukkan bahwa sebagian besar skor kelas eksperimen cenderung sangat tinggi, sementara pada kelas kontrol cenderung tinggi. Jika dikonversikan rata - rata pemahaman konsep IPA kelas eksperimen dan kelas kontrol dengan katagori pada skala lima diperoleh rata - rata skor pemahaman konsep IPA siswa pada kelas eksperimen adalah 25,06 termasuk pada kategori sangat tinggi. Sementara hasil rata - rata skor pemahaman konsep IPA siswa kelas kontrol adalah 21,00 pada ketegori tinggi. Hal ini menunjukkan bahwa pemahaman konsep IPA pada kelas eksperimen lebih baik dibandingkan dengan pemahaman konsep IPA pada kelas kontrol.

Sedangkan pada sikap ilmiah sebaran data kelas eksperimen mean sebesar 127,67 modus sebesar 127,00 median sebesar 127,00 skor maksimum 150 skor minimum 105. Sementara sebaran data pada kelas kontrol mean sebesar 114,19 modus sebesar 125,31 median sebesar 113,69 skor maksimum 138, skor minimum 98. Dari sebaran data skor sikap ilmiah siswa pada kelas eksperimen dan kelas kontrol menunjukkan bahwa sebagian besar skor kelas eksperimen cenderung sangat tinggi, sementara pada kelas kontrol cenderung tinggi. Jika dikonversikan rata - rata sikap ilmiah kelas eksperimen dan kelas kontrol dengan katagori pada skala lima diperoleh rata - rata skor sikap ilmiah pada kelas eksperimen adalah 127,67 termasuk pada kategori sangat tinggi. Sementara hasil rata - rata skor sikap ilmiah kelas kontrol adalah 114,19 pada ketegori tinggi. Hal ini menunjukkan bahwa sikap ilmiah pada 
kelas eksperimen lebih baik dibandingkan dengan kompeetensi pengetahuan pada kelas kontrol.

Setelah dilakukan analisis deskriptif pada pemahaman konsep IPA dan sikap ilmiah kelas eksperimen dan kelas kontrol kemudian dilanjutkan uji hipotesis menggunakan metode statistik dengan uji ANAVA dan MANOVA. Sebelum uji hipotesis dilakukan terlebih dahulu dilakukan uji prasyarat yaitu uji normalitas, homogenitas dan korelasi antar variabel terikat. Berdasarkan uji normalitas data menggunakan Kolmogorov Smirnov dengan bantuan SPSS 21, yang disajikan pada Tabel 3.

Tabel 3 Rekapitulasi Hasil Pengujian Normalitas Sebaran Data dengan Shapiro-Wilk

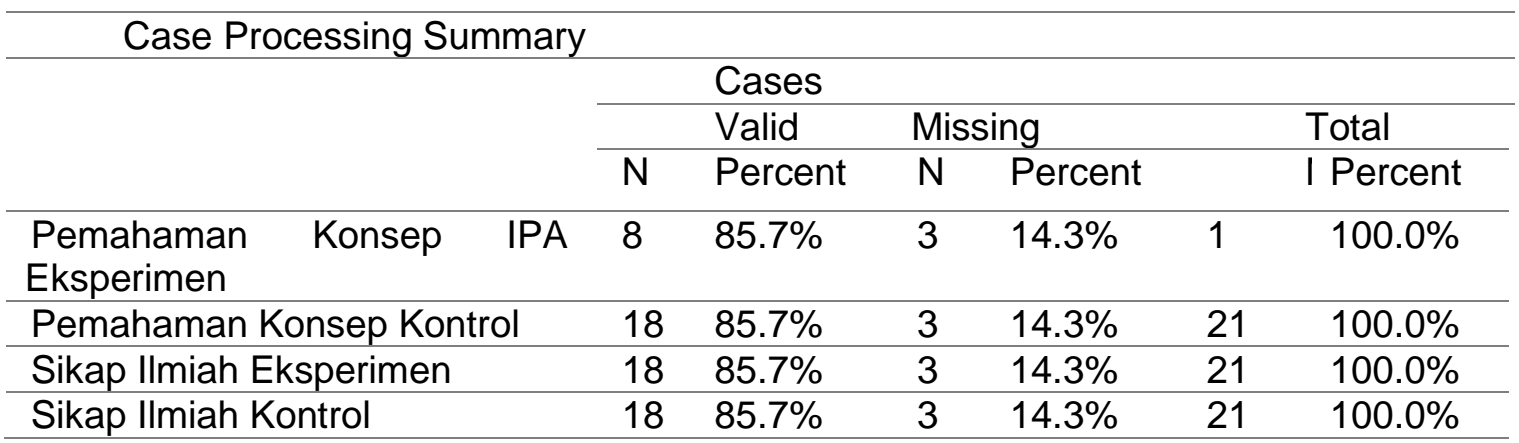

Tabel 4. Rekapitulasi Hasil Pengujian Normalitas Sebaran Data dengan Uji KolmogorovSmirnov

Tests of Normality

\begin{tabular}{|c|c|c|c|c|c|c|c|}
\hline \multirow{2}{*}{\multicolumn{2}{|c|}{ 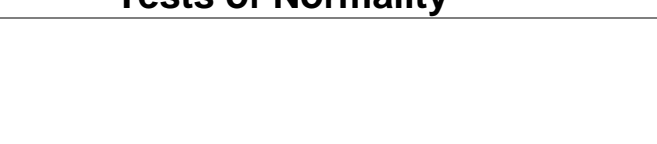 }} & \multicolumn{3}{|c|}{ Kolmogorov-Smirnov ${ }^{\mathrm{a}}$} & \multicolumn{3}{|c|}{ Shapiro-Wilk } \\
\hline & & $\begin{array}{l}\text { Statis } \\
\text { tic }\end{array}$ & df & Sig. & $\begin{array}{l}\text { Statis } \\
\text { tic }\end{array}$ & df & Sig. \\
\hline $\begin{array}{l}\text { Pemahaman } \\
\text { Eksperimen }\end{array}$ & IPA & .161 & 18 & $.200^{*}$ & .900 & 18 & .068 \\
\hline Pemahaman Konsep Kontrol & & .115 & 18 & $.200^{*}$ & .928 & 18 & .181 \\
\hline Sikap IImiah Eksperimen & & .172 & 18 & .171 & .921 & 18 & .134 \\
\hline Sikap Ilmiah Kontrol & & .134 & 18 & $.200^{*}$ & .923 & 18 & .147 \\
\hline
\end{tabular}

*. This is a lower bound of the true significance.

a. Lilliefors Significance Correction

Dari hasil uji normalitas dengan uji Kolmogorov-Smirnov dan ShapiroWilk didapatkan hasil signifikansi diatas $>0,05$ atau $5 \%$, maka dapat disimpulkan data berdistribusi normal.

Tabel 5 Rekapitulasi Hasil Uji Homogenitas Varians berbantuan SPSS 21 For Windows

\section{Test of Homogeneity of Variances}

\begin{tabular}{lllll}
\hline & Levene Statistic & df1 & df2 & Sig. \\
\hline Pemahaman Konsep & 2.285 & 1 & 37 & .139 \\
\hline Sikap Ilmiah & 1.756 & 1 & 37 & .193 \\
\hline
\end{tabular}

Dari hasil uji homogenitas dengan menggunakan uji Levene Statistic didapatkan hasil skor pemahaman konsep IPA signifikansinya sebesar 0,139>0,05 dan hasil didapatkan juga hasil skor sikap ilmiah signifikansinya 0,193>0,05 maka data pemahaman konsep IPA dan sikap ilmiah siswa berdistribusi homogen. 
Tabel 6 Hasil Uji Korelasi Product Moment Kelompok Eksperimen

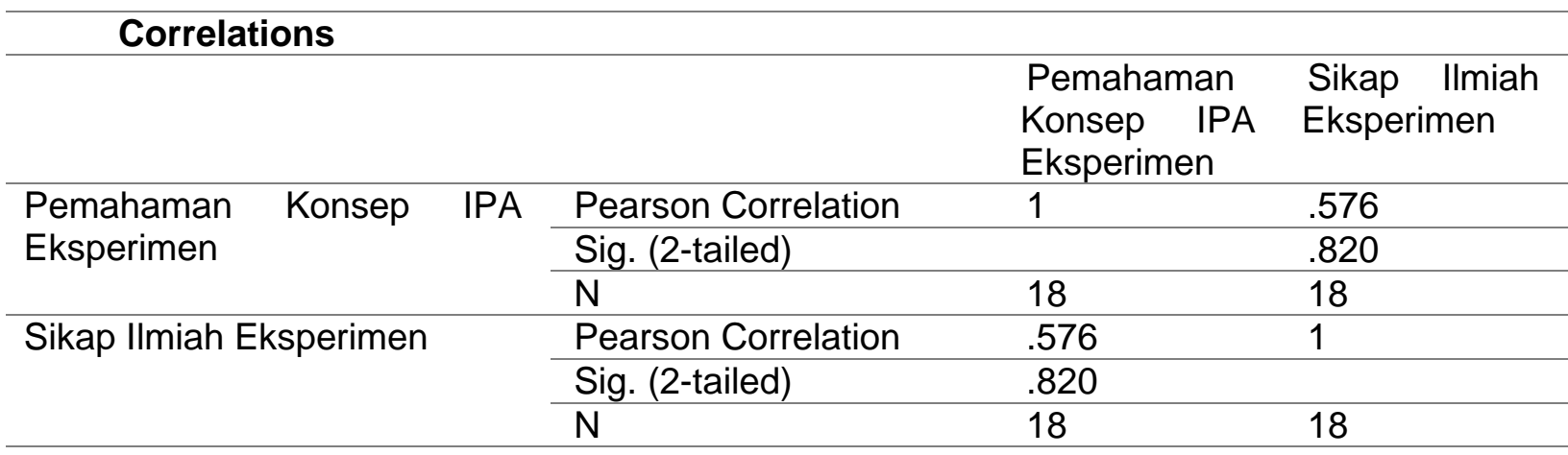

Hasil Uji Korelasi Product Moment antar varians kelompok eksperimen menunjukkan hasil signifikansi 0,576>0,05 hasil tersebut dapat disimpulkan bahwa antar varians kelompok eksperimen tidak berkorelasi.

Tabel 7 Hasil Uji Korelasi Product Moment Kelompok Kontrol

\begin{tabular}{|c|c|c|c|}
\hline \multicolumn{4}{|l|}{ Correlations } \\
\hline & & Pemahama & Sikap \\
\hline & & $\begin{array}{l}\text { n Konsep } \\
\text { IPA Kontrol }\end{array}$ & $\begin{array}{l}\text { Ilmiah } \\
\text { Kontrol }\end{array}$ \\
\hline \multirow[t]{3}{*}{ Pemahaman Konsep IPA Kontrol } & Pearson Correlation & 1 & .312 \\
\hline & Sig. (2-tailed) & & .168 \\
\hline & $\mathrm{N}$ & 21 & 21 \\
\hline \multirow[t]{3}{*}{ Sikap IImiah Kontrol } & Pearson Correlation & .312 & 1 \\
\hline & Sig. (2-tailed) & .168 & \\
\hline & $\mathrm{N}$ & 21 & 21 \\
\hline
\end{tabular}

Hasil Uji Korelasi Product Moment antar varians kelompok kontrol menunjukkan hasil signifikansi 0,312>0,05 hasil tersebut dapat disimpulkan bahwa antar varians kelompok eksperimen tidak berkorelasi.

Tabel 8 Hasil Uji Hipotesis 1 dengan ANAVA satu jalur berbantuan SPSS 21 for Windows

\begin{tabular}{|c|c|c|c|c|c|c|c|c|}
\hline \multicolumn{9}{|l|}{ Descriptives } \\
\hline \multicolumn{9}{|c|}{ PEMAHAMAN KONSEP IPA } \\
\hline & \multirow[t]{2}{*}{$\mathrm{N}$} & \multirow[t]{2}{*}{ Mean } & \multirow{2}{*}{$\begin{array}{l}\text { Std. } \\
\text { Deviatio } \\
n\end{array}$} & \multirow[t]{2}{*}{$\begin{array}{l}\text { Std. } \\
\text { Error }\end{array}$} & $\begin{array}{l}95 \% \\
\text { Interva }\end{array}$ & $\begin{array}{l}\text { Confidence } \\
\text { or Mean }\end{array}$ & \multirow[t]{2}{*}{$\begin{array}{l}\text { Mini } \\
\text { mum }\end{array}$} & \multirow[t]{2}{*}{$\begin{array}{l}\text { Maxi } \\
\text { mum }\end{array}$} \\
\hline & & & & & $\begin{array}{l}\text { Lower } \\
\text { Bound }\end{array}$ & $\begin{array}{l}\text { Upper } \\
\text { Bound }\end{array}$ & & \\
\hline EKSPERIMEN & 18 & 25.06 & 4.123 & .972 & 23.01 & 27.11 & 18 & 30 \\
\hline KONTROL & 21 & 21.00 & 2.881 & .629 & 19.69 & 22.31 & 17 & 26 \\
\hline Total & 39 & 22.87 & 4.021 & .644 & 21.57 & 24.18 & 17 & 30 \\
\hline
\end{tabular}

\begin{tabular}{lllll}
\hline Test of Homogeneity of Variances & & & \\
\hline PEMAHAMAN KONSEP IPA & & & \\
\hline Levene Statistic & df1 & df2 & Sig. \\
\hline 2.285 & 1 & 37 & .139 \\
\hline
\end{tabular}




\begin{tabular}{|c|c|c|c|c|c|}
\hline $\begin{array}{l}\text { ANOVA } \\
\text { PEMAHAMAN KC }\end{array}$ & IPA & & & & \\
\hline & Sum of Squares & Df & Mean Square & $\mathrm{F}$ & Sig. \\
\hline Between Groups & 159.415 & 1 & 159.415 & 12.965 & .001 \\
\hline Within Groups & 454.944 & 37 & 12.296 & & \\
\hline Total & 614.359 & 38 & & & \\
\hline
\end{tabular}

Dari Hasil uji Hipotesis I menggunakan uji anova didapatkan hasil signifikansi sebesar $0,001<0,05$, sehingga $\mathrm{H}_{0}$ ditolak dan $\mathrm{H}_{1}$ diterima. Dapat disimpulkan bahwa terdapat pengaruh yang signifikan model pembelajaran Inkuiri Terbimbing terhadap pemahaman konsep IPA siswa kelas IV di SD Gugus VII Kecamatan Mengwi Kabupaten Badung Tahun Pelajaran 2018/2019.

Tabel 9. Hasil Uji Hipotesis 2 dengan ANAVA satu jalur berbantuan SPSS 21 for Windows

\begin{tabular}{|c|c|c|c|c|c|c|c|c|}
\hline \multicolumn{9}{|c|}{ Descriptives } \\
\hline \multicolumn{9}{|c|}{ SIKAP ILMIAH } \\
\hline & \multirow[t]{2}{*}{$\mathrm{N}$} & \multirow[t]{2}{*}{$\begin{array}{l}\text { Mea } \\
\mathrm{n}\end{array}$} & \multirow{2}{*}{$\begin{array}{l}\text { Std. } \\
\text { Deviatio } \\
n\end{array}$} & \multirow[t]{2}{*}{$\begin{array}{l}\text { Std. } \\
\text { Error }\end{array}$} & \multicolumn{2}{|c|}{$\begin{array}{l}95 \% \\
\text { Interval for Mean }\end{array}$} & \multirow[t]{2}{*}{$\begin{array}{l}\text { Minim } \\
\text { um }\end{array}$} & \multirow[t]{2}{*}{$\begin{array}{l}\text { Maxi } \\
\text { mum }\end{array}$} \\
\hline & & & & & $\begin{array}{l}\text { Lower } \\
\text { Bound }\end{array}$ & $\begin{array}{l}\text { Upper } \\
\text { Bound }\end{array}$ & & \\
\hline $\begin{array}{l}\text { EKSPERI } \\
\text { MEN }\end{array}$ & 18 & $\begin{array}{l}127 . \\
67\end{array}$ & 15.778 & 3.719 & 119.82 & 135.51 & 105 & 150 \\
\hline $\begin{array}{l}\text { KONTRO } \\
\text { L }\end{array}$ & 21 & $\begin{array}{l}114 . \\
19\end{array}$ & 12.564 & 2.742 & 108.47 & 119.91 & 98 & 134 \\
\hline Total & 39 & $\begin{array}{l}120 . \\
41\end{array}$ & 15.517 & 2.485 & 115.38 & 125.44 & 98 & 150 \\
\hline
\end{tabular}

Test of Homogeneity of Variances

SIKAP ILMIAH

Levene Statistic

1.756

df1

df2

Sig.

$1 \quad 37$

.193

\begin{tabular}{l} 
ANOVA \\
\hline SIKAP ILMIAH \\
\hline
\end{tabular}

Dari Hasil uji Hipotesis II menggunakan uji anova didapatkan hasil signifikansi sebesar $0,005<0,05$, sehingga $\mathrm{H}_{0}$ ditolak dan $\mathrm{H}_{1}$ diterima. Dapat disimpulkan bahwa terdapat pengaruh yang signifikan model pembelajaran Inkuiri Terbimbing terhadap sikap ilmiah siswa kelas IV di SD Gugus VII Kecamatan Mengwi Kabupaten Badung Tahun Pelajaran 2018/2019 
Tabel 10 Hasil Uji Hipotesis 3 dengan MANOVA berbantuan SPSS 21 for Windows

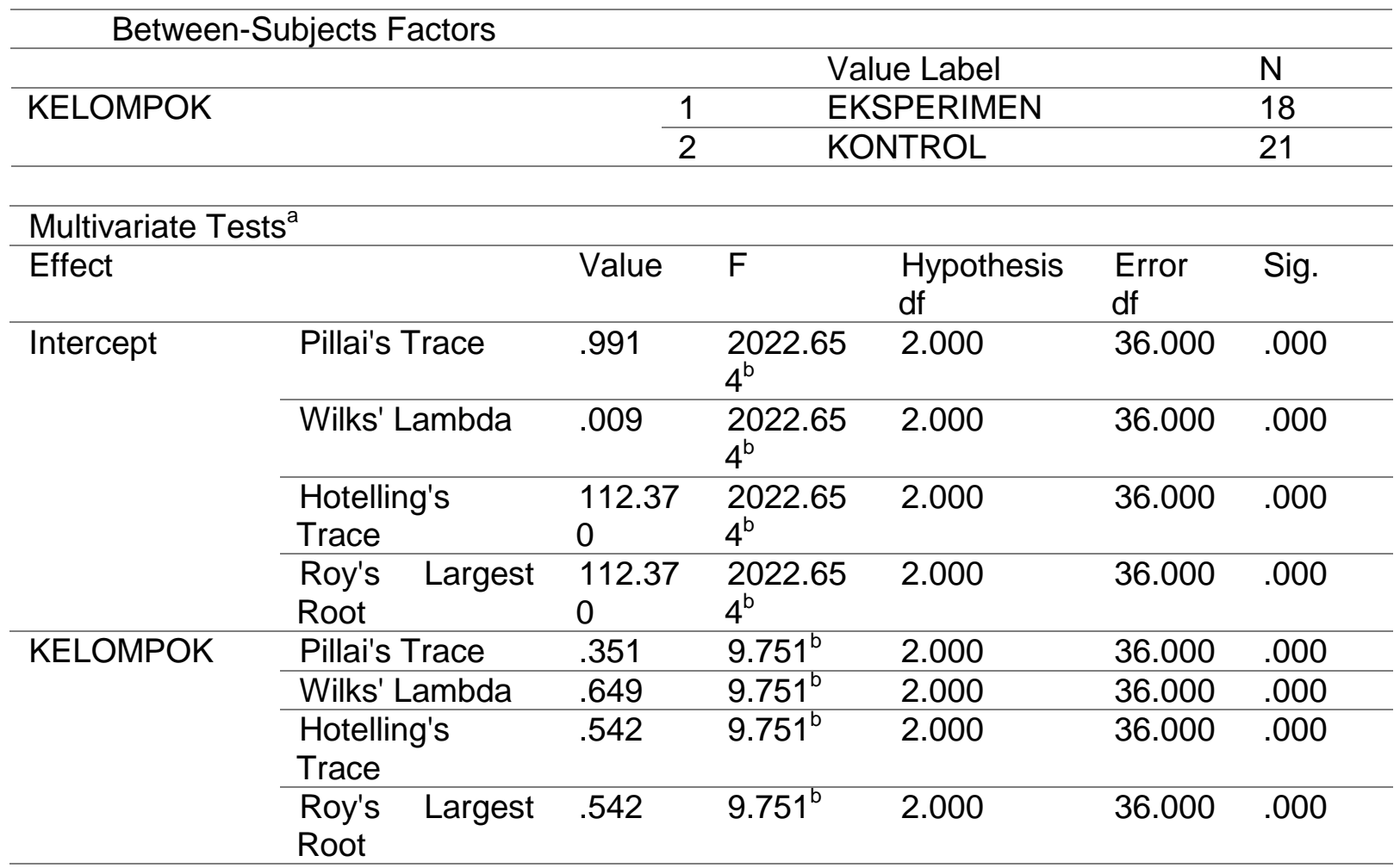

a. Design: Intercept + KELOMPOK

b. Exact statistic

\begin{tabular}{|c|c|c|c|c|c|c|}
\hline \multicolumn{7}{|c|}{ Tests of Between-Subjects Effects } \\
\hline \multirow[t]{3}{*}{ Source } & Dependent Variable & Type III & df & Mean & $\mathrm{F}$ & Sig. \\
\hline & & Sum of & & Square & & \\
\hline & & Squares & & & & \\
\hline \multirow{2}{*}{$\begin{array}{l}\text { Corrected } \\
\text { Model }\end{array}$} & SIKAP ILMIAH & $159.415^{\mathrm{a}}$ & 1 & 159.415 & 12.965 & .001 \\
\hline & $\begin{array}{l}\text { PEMAHAMAN } \\
\text { KONSEP IPA }\end{array}$ & $1760.198^{b}$ & 1 & 1760.198 & 8.814 & .005 \\
\hline \multirow[t]{2}{*}{ Intercept } & SIKAP ILMIAH & 20558.491 & 1 & $\begin{array}{l}20558.49 \\
1\end{array}$ & $\begin{array}{l}1671.9 \\
94\end{array}$ & .000 \\
\hline & $\begin{array}{l}\text { PEMAHAMAN } \\
\text { KONSEP IPA }\end{array}$ & $\begin{array}{l}566950.35 \\
2\end{array}$ & 1 & $\begin{array}{l}566950.3 \\
52\end{array}$ & $\begin{array}{l}2838.8 \\
80\end{array}$ & .000 \\
\hline \multirow{2}{*}{$\begin{array}{l}\text { KELOMPO } \\
\text { K }\end{array}$} & SIKAP ILMIAH & 159.415 & 1 & 159.415 & 12.965 & .001 \\
\hline & $\begin{array}{l}\text { PEMAHAMAN } \\
\text { KONSEP IPA }\end{array}$ & 1760.198 & 1 & 1760.198 & 8.814 & .005 \\
\hline \multirow[t]{2}{*}{ Error } & SIKAP ILMIAH & 454.944 & 37 & 12.296 & & \\
\hline & $\begin{array}{l}\text { PEMAHAMAN } \\
\text { KONSEP IPA }\end{array}$ & 7389.238 & 37 & 199.709 & & \\
\hline \multirow[t]{2}{*}{ Total } & SIKAP ILMIAH & 21016.000 & 39 & & & \\
\hline & $\begin{array}{l}\text { PEMAHAMAN } \\
\text { KONSEP IPA }\end{array}$ & $\begin{array}{l}574596.00 \\
0\end{array}$ & 39 & & & \\
\hline \multirow{2}{*}{$\begin{array}{l}\text { Corrected } \\
\text { Total }\end{array}$} & SIKAP ILMIAH & 614.359 & 38 & & & \\
\hline & $\begin{array}{l}\text { PEMAHAMAN } \\
\text { KONSEP IPA }\end{array}$ & 9149.436 & 38 & & & \\
\hline
\end{tabular}

a. R Squared $=, 259$ (Adjusted R Squared $=, 239$ ) 


\section{b. R Squared $=, 192$ (Adjusted R Squared $=, 171$ )}

Berdasarkan analisis pada tabel, nilai F Pillai's Trace, Wilks' Lambda, Hotel;ing Trace, Roy's Largest Root adalah 112,370 seluruhnya memiliki signifikansi 0,000 dan lebih kecil dari $0,05(0,000<0,05)$, sehingga $\mathrm{H}_{0}$ ditolak dan $\mathrm{H}_{1}$ diterima. Berdasarkan analisis uji hipotesis 3 dapat disimpulkan bahwa secara simultan terdapat pengaruh yang signifikan model pembelajaran Inkuiri Terbimbing terhadap Pemahaman Konsep IPA dan Sikap IImiah pada siswa kelas IV di SD Gugus VII Kecamatan Mengwi Kabupaten Badung Tahun Pelajaran 2018/2019.

Pada penelitian ini yang dibandingkan adalah: (1) pemahaman konsep IPA siswa yang mengikuti model pembelajaran Inkuiri Terbimbing, (2) sikap ilmiah yang mengikuti model pembelajaran Inkuiri Terbimbing, (3) pemahaman konsep IPA siswa yang tidak mengikuti model pembelajaran inkuiri terbimbing, (4) sikap ilmiah yang tidak mengikuti model pembelajaran inkuiri terbimbing. Hasil penelitian ini menunjukkan bahwa pemahaman konsep dan sikap ilmiah IPA siswa kelompok eksperimen berbeda dengan siswa kelompok kontrol. Hal tersebut merujuk pada hasil pengujian hipotesis dan analisis data yang telah dilakukan.

Secara umum, hasil analisis data menujukkan terdapat perbedaan baik yaitu hasil pemahaman konsep IPA siswa yang mengikuti model pembelajaran Inkuiri Terbimbing dengan siswa yang tidak mengikuti model pembelajaran inkuiri terbimbing. Setelah melaksanakan penelitian selama 7 kali pertemuan diperoleh hasil skor rata-rata siswa yang mengikuti model pembelajaran Inkuiri Terbimbing adalah 25,10 sedangkan siswa yang tidak mengikuti model pembelajaran inkuiri terbimbing memperoleh rata-rata skor yaitu 21,00. Hal ini menujukkan pemahaman konsep IPA yang mengikuti model pembelajaran Inkuiri Terbimbing lebih tinggi dibandingkan siswa yang tidak mengikuti model pembelajaran inkuiri terbimbing.

Selain itu hasil analisis data sikap ilmiah siswa menunjukkan terdapat perbedaan antara sikap ilmiah siswa yang mengikuti model pembelajaran Inkuiri Terbimbing dengan siswa yang tidak mengikuti model pembelajaran inkuiri terbimbing. Siswa yang mengikuti model pembelajaran Inkuiri Terbimbing memperoleh rata-rata skor 127,67 sedangkan siswa yang tidak mengikuti model pembelajaran inkuiri terbimbing memperoleh rata-rata skor 114,19 . Hal ini menunjukkan sikap ilmiah siswa yang mengikuti model pembelajaran Inkuiri Terbimbing lebih tinggi dibandingkan siswa yang tidak mengikuti model pembelajaran inkuiri terbimbing.

Hasil analisis data pemahaman konsep IPA dan sikap ilmiah siswa, menunjukkan terdapat perbedaan antara siswa yang yang mengikuti model pembelajaran Inkuiri Terbimbing dengan siswa yang tidak mengikuti model pembelajaran inkuiri terbimbing. Hal ini dibuktikan dengan siswa yang mengikuti model pembelajaran Inkuiri Terbimbing memperoleh hasil analisis, nilai F Pillai's Trace, Wilks' Lambda, Hotel;ing Trace, Roy's Largest Root adalah 112,370 seluruhnya memiliki signifikansi 0,000 dan lebih kecil dari $0,05(0,000<0,05)$.

Selain itu model pembelajaran Inkuiri Terbimbing dalam proses pembelajaran dapat melibatkan siswa secara penuh sehingga siswa dapat meningkatkan cara memahami konsep materi pembelajaran dan dapat melatih sikap ilmiah siswa serta dapat membentuk dan mengembangkan dirinya sendiri hal ini sejalan dengan pendapat Roetiyah (dalam Nurdin, 2016) yang menyatakan model pembelajaran Inkuiri Terbimbing memiliki beberapa keunggulan yaitu: (1)dapat membentuk dan mengembangkan "self concept" pada diri siswa sehingga siswa dapat menegerti tentang konsep dasar ide-ide lebih baik, (2) membantu dalam menggunakan ingatan daan transfer pada situasi proses belajar yang baru, (3) mendorong siswa untuk berfikir dan bekerja atas inisiatifnya sendiri bersikap objektif, jujur dan terbuka, (4) mendorong siswa untuk berfikir intuituf dan merumuskan hipotesisnya sendiri, (5)memberi kepuasan yang bersifat intrinsic, (6) situasi proses belajar menjadi lebih merangsang, (7) dapat mengembangkan bakat atau kecakapan individu, (8) memberi kebebasan siswa untuk belajar sendiri, (9) siswa dapat menghindari cara-cara belajar tradisional, (10) dapat memberikan waktu pada siswa secukupnya sehingga mereka dapat mengasimilasi dan mengakomodasi informasi.

Hasil penelitian ini juga diperkuat oleh penelitian yang dilakukan oleh Artayana (2013) menunjukkan bahwa terdapat perbedaan pemahaman konsep IPA siswa yang dibelajarkan 
dengan menggunakan model pembelajaran Inkuiri Terbimbing dan kelompok siswa yang tidak dibelajarkan dengan model pembelajaran Inkuiri Terbimbing, Puspawati (2013) menunjukkan bahwa terdapat perbedaan pemahaman konsep IPA kelompok siswa yang dibelajarkan dengan mengunakan model pembelajaran Inkuiri Terbimbing berbantuan media konkret dan kelompok siswa yang tidak dibelajarkan dengan model pembelajaran Inkuiri Terbimbing berbantuan media konkret, Rusitha (2013) menunjukkan bahwa terdapat perbedaan pemahaman konsep IPA kelompok siswa yang dibelajarkan dengan menggunakan model pembelajaran Inkuiri Terbimbing berbantuan teknik peta konsep dan kelompok siswa yang tidak dibelajarkan dengan menggunakan model pembelajaran Inkuiri Terbimbing berbantuan teknik peta konsep. Menurut penelitian Fenica (2017) Penerapan model pembelajaran Inkuiri Terbimbing dapat meningkatkan aktivitas belajar siswa. Selain itu penelitian NM Susanti (2017) menemukan bahwa pembelajaran inkuiri terbimbing dapat meningkatkan aktivitas dan hasil belajar siswa.

\section{Simpulan dan Saran}

Berdasarkan hasil pengujian hipotesis dan pembahasan hasil penelitian, maka simpulan dari penelitian ini adalah sebagai berikut.

1. Terdapat perbedaan yang signifikan pemahaman konsep IPA antara siswa yang dibelajarkan dengan model pembelajaran inkuiri terbimbing dan siswa yang tidak dibelajarkan dengan model pembelajaran inkuiri terbimbing pada siswa kelas IV Gugus VII Kecamatan Mengwi Kabupaten Badung Tahun pembelajaran 2018/2019 hal tersebut diperoleh dari uji anova didapatkan hasil signifikansi sebesar $0,001<0,05$, sehingga $\mathrm{HO}$ ditolak dan $\mathrm{H} 1$ diterima.

2. Terdapat perbedaan yang signifikan sikap ilmiah antara siswa yang dibelajarkan dengan model pembelajaran inkuiri terbimbing dan siswa yang tidak dibelajarkan dengan model pembelajaran inkuiri terbimbing pada siswa kelas IV Gugus VII Kecamatan Mengwi Kabupaten Badung Tahun pembelajaran 2018/2019 hal tersebut diperoleh dari uji anova didapatkan hasil signifikansi sebesar $0,005<0,05$, sehingga $\mathrm{H} 0$ ditolak dan $\mathrm{H} 1$ diterima.

3. Secara simultan terdapat perbedaan yang signifikan pemahaman konsep IPA dan sikap ilmiah antara siswa yang dibelajarkan dengan model pembelajaran inkuiri terbimbing dan siswa yang tidak dibelajarkan dengan model pembelajaran inkuiri terbimbing pada siswa kelas IV Gugus VII Kecamatan Mengwi Kabupaten Badung Tahun pembelajaran 2018/2019 hal itu diperoleh dari analisis pada tabel, nilai F Pillai's Trace, Wilks' Lambda, Hotel;ing Trace, Roy's Largest Root adalah 112,370 seluruhnya memiliki signifikansi 0,000 dan lebih kecil dari $0,05(0,000<0,05)$, sehingga $\mathrm{H} 0$ ditolak dan $\mathrm{H} 1$ diterima.

\section{Daftar Pustaka}

Agung. A. A. Gede. 2014. Metodologi Penelitian Pendidikan. Malang: Aditya Media Publishing.

Agung. A. A. Gede. 2016. Statitiska Dasar untuk Pendidikan. Yogyakarta: Deepublish.

Artayana, Pt. Erwin, 2013 "Penerapan Model Inkuiri Untuk Meningkatkan Pemahaman Konsep IPA Dan Sikap IImiah Siswa Kelas IV SDN 1 Depeha Kecamatan Kubutambahan" Vol. 1, No 1.Tersedia Pada: https://ejournal.undiksha.ac.id/index.php/JJPGSD/article/view/842 Diakses, 20 Januari 2019

Bundu, P. 2006.Penilaian Ketrampilan Proses Dan Sikap IImiah Dalam Pembelajaran Sains Sekolah Dasar. Jakarta: Depdiknas Dirjen Pendidikan Tinggi Direktorat Ketenagaan.

Candiasa, I Made, 2010, Statistik Multivariat Dirsertai SPSS. Singaraja: Undiksha Pers

Candiasa, I Made. 2011, Pengujian Instrument Penelitian Disertai Aplikasi ITEMAN dan BIGSTEP. Singaraja: Undiksha Pers. 
Dantes, Nyoman. 2014. Landasan Pendidikan Tinjauan Dari Dimensi Makropedagogis. Singaraja: Graha IImu.

Dwi Ariantari, Ni Md, dkk. 2013. "Pengaruh Model Pembelajaran Tandur terhadap Pemahaman Konsep IPA Siswa Kelas IV Sekolah Dasar Gugus VI Kecamatan Buleleng”. Ejournal PGSD Universitas Pendidikan Ganesha Mimbar Pgsd, Vol. 1, No. 1, Tahun 2013.Tersediapada:https://ejournal.undiksha.ac.id/index.php/JJPGSD/article/view/893.

Diakses tanggal 13 Juli 2019.

Fenica, I., Muderawan, I. W., \& Widiartini, P. (2017). Implementasi Model Pembelajaran Inkuiri Untuk Meningkatkan Aktivitas Belajar Siswa Pada Mata Pelajaran Kimia. Jurnal Pendidikan Kimia Indonesia, 1(1), 1-6.

Koyan, I Wayan, 2011, Assasment dalam Pendidikan, Singaraja: Universitas Pendidikan Ganesha

Koyan, I Wayan. 2012, Statistitik Pendidikan Teknik Analisis Data Kuantitatif cetakan Pertama, Singaraja: Universitas Pendidikan Ganesha

Sagita Krissandi, A.D. 2017. Pembelajaran Bahasa Indonesia untuk SD (Pendekatan Teknis). Bekasi: Media Maxima

Setyosari. 2015. Metode Penelitian pendidikan dan pengembangan. Jakarta:Prenadamedia Group.

Sudana, Dewa Nyoman, 2016, Buku Ajar Perguruan Tinggi Pendidikan IPA SD, Singaraja: Universitas Pendidikan Ganesha.

Hawkins, H.S. 1999. Penyuluhan Pertanian. Yogyakarta: Kanisius

Kt. Puspawati. 2013. "Pengaruh Model Pembelajaran Inkuiri Terbimbing Berbantuan Media Konkret Terhadap Pemahaman Konsep IPA Siswa Kelas V SD Gugus V Kecamatan Buleleng" Ejournal PGSD Universitas Pendidikan Ganesha Mimbar Pgsd, Vol 1, No 1 2013. Tersedia pada

https://ejournal.undiksha.ac.id/index.php/JJPGSD/article/view/1282/1143.

Diakses tanggal 13 Juli 2019.

Linda Jayanthi, Ni Wayan, dkk. 2013. "Pengaruh Metode PQRST terhadap Pemahaman Konsep IPA Siswa Kelas V SD di Gugus V Kecamatan Kediri". Ejournal PGSD Universitas Pendidikan Ganesha Mimbar Pgsd, Vol. 1, No. 1, Tahun 2013. Tersedia pada: https://ejournal.undiksha.ac.id/index.php/JJPGSD/article/view/751. Diakses tanggal 13 Juli 2019.

L. Pt. Mutiara Rushita Adi, 2013 "Pengaruh Model Pembelajaran Inkuiri Terbimbing Berbantuan Teknik Peta Konsep Terhadap Pemahaman Konsep IPA Siswa Kelas V SD Di Desa Kaliasem" Ejournal PGSD Universitas Pendidikan Ganesha Mimbar Pgsd, Vol 1, No 1 2013.

Tersediapada:https://ejournal.undiksha.ac.id/index.php/JJPGSD/article/view/794Diakses tanggal 13 Juli 2019.

Nurdin, Syafruddin. 2016. Kurikulum dan Pembelajaran. Jakarta: Rajawali Pers 
Putri Widya Astuti, Ni Md, dkk. 2013. "Pengaruh Strategi Concept Mapping Berbantuan Media Presentasi Pembelajaran terhadap Pemahaman Konsep IPA Siswa Kelas IV Sekolah Dasar di Desa Lelateng". Ejournal PGSD Universitas Pendidikan Ganesha Mimbar Pgsd, Vol 1, No. 1, Tahun 2013. Tersedia pada : https://ejournal.undiksha.ac.id/index.php/JJPGSD/article/view/1282.Diakses tanggal 13 Juli 2019.

Riastini, Nanci dkk. 2016. Pembelajaran IPA SD. Singaraja: Undiksha

Sanjaya, Wina. 2008. Perencanaan Sistem Pembelajaran. Jakarta: Kencana

Sanjaya, Wina. 2008. Kurikulum dan Pembelajaran. Jakarta: Kencana

Sanjaya, Wina.2009. Strategi Pembelajaran Berorientasi Standar Proses Pendidikan Jakarta: Kencana Prenada Media Group

Samatowa. 2010. Pembelajaran IPA di Sekolah Dasar. Jakarta Barat: PT Indeks.

Susanti, N. M., Suardana, I. N., \& Suwenten, M. (2017). Penerapan Model Pembelajaran Guided Inquiry Untuk Meningkatkan Aktivitas Dan Hasil Belajar Kimia Di Kelas X MIPA. Jurnal Pendidikan Kimia Indonesia, 1(2), 53-59.

Susanto. 2014. Teori Belajar dan Pembelajaran di Sekolah Dasar. Jakarta: Kencana.

Sunaryo. 2004. Psikologi untuk keperawatan. Jakarta: Buku Kedokteran EGC

Sugiono, 2016. Metode Penelitian Pendidikan Pendekatan Kuantitatif, Kualitatif dan R\&D. Alfabeta Bandung

Trianto. 2007. Model Pembelajaran Terpadu dalam Teori dan Praktek Jakarta: Prestasi Pustaka

Trianto. 2009. Mendesain Model Pembelajaran Inovatif-Progresif. Jakarta: Kencana Prenada Media Group.

Trianto. 2012. Model Pembelajaran Terpadu. Jakarta:PT Bumi Aksara

Zubaedi. 2011. Desain Pendidikan Karakter Konsepsi dan Aplikasinya dalam Lembaga Pendidikan. Jakarta: Kencana Prenada Media Group. 